Omni-Akuatika, 14 (2): 132 -137, 2018
ISSN: 1858-3873 print / 2476-9347 online
Research Article
journal homepage: http://ojs.omniaquatika.net

\title{
Polyculture Engineering of White Shrimp Vannamei and Seaweed on Different Planting Distance on The Growth, Survival in Abration Pond
}

\author{
Istiyanto Samidjan $^{1^{*}}$, Diana Rachmawati $^{1}$ \\ ${ }^{1}$ Lecturer Department of aquaculture, fisheries and Marine Science Faculty of Diponegoro University \\ JI. Prof. Sudharto,SH, Kampus Tembalang, Semarang, Indonesia \\ *Corresponding authors: istiyanto_samidjan@yahoo.com
}

\begin{abstract}
The objective of the study was to assess the role of polyculture engineering of vanamei shrimp, and seaweed in an effort to increase growth and survival. The experimental method was randomized complete design with 4 treatments and 3 replications were $\mathrm{T} 1\left(10 \mathrm{PL} / \mathrm{m}^{2}\right.$ white shrimp vannamei and seaweed distance $15 \mathrm{~cm}$ ), T2 (10 PL / $\mathrm{m}^{2}$ of white shrimp vannamei and seaweed distance $\left.30 \mathrm{~cm}\right)$, T3 (10 PL / $\mathrm{m}^{2}$ white shrimp vanamei and seaweed distance $45 \mathrm{~cm}$, T4 $\left(10 \mathrm{PL} / \mathrm{m}^{2}\right.$ white shrimp vanamei and seaweed $60 \mathrm{~cm}$ ). Seaweed used Gracillaria sp type $150 \mathrm{~g} /$ bundle with treatment used a long line system placed around the nets plot of $1 \mathrm{~m}^{2}$ in pond culture $300 \mathrm{~m}^{2}$. Data includes the growth of absolute weight, survival, FCR were analyzed variety and test Tukey. observation of the water quality of maintenance media include nitrite, ammonia, temperature, $\mathrm{pH}$, salinity using descriptive. There is a very real effect $(P<0.01)$ on treatment with different plant spacing on seaweed and vanamei shrimp on growth and survival of white shrimp vanamei and seaweed. The highest absolute weight growth in vanamei shrimp was T4 treatment (vanamei shrimp $29.25 \pm 0.07 \mathrm{~g}$ ), and seaweed $\left(2919.03 \pm 8.70^{\mathrm{b}} \mathrm{g}\right)$ of white shrimp vanamei survival rate $(98.25 \% \pm 2.25 \%$ ) and FCR (food Conversion ratio) $1.15 \pm 0.09$. Water quality is still feasible optimum.
\end{abstract}

Keywords: Polyculture, white shrimp vanamei, growth, survival

\section{Introduction}

Polyculture technology is simultaneously maintaining two species or more maintained in the pond. This polyculture can be done, among others, by simultaneously maintaining vanamei shrimp and Gracillaria sp. This polluting technology is more profitable than monoculture because it can produce higher production and the economic value of milkfish and seaweed is also higher.

The objective of research was to the role polyculture engineering of vanamei shrimp (litopenaeus vannamei, Boone), and seaweed in an effort to increase growth and survival, the reason for using experimental animals is vanamei shrimp and seaweed polyculture, because it has a mutually beneficial relationship symbiosis occurs, in which vanamei shrimp excrete dirt and the remaining feed is decomposed into detritus then converted into nitrogenous nutrients, phosphate and potassium. The nutrient is used by seaweed as fertilizer, so it can accelerate the growth of seaweed. Likewise vice versa seaweed is used by shrimp Vanamei as a shelter from sunlight (ultra vioet) which kills vanamei shrimp. Planting seaweed determines the growth and utilization of detritus as seaweed fertilizer to grow to the maximum.

\section{Materilas and Methods}

\subsection{Materials}

The experimental method was randomized complete design with 4 treatments and 3 replications were $\mathrm{T} 1$ (10 post larvae (PL) $/ \mathrm{m}^{2}$ white shrimp vannamei and seaweed distance $15 \mathrm{~cm})$, T2 (10 PL / $\mathrm{m}^{2}$ of white shrimp vannamei and seaweed distance $30 \mathrm{~cm})$, T3 (10 PL / $\mathrm{m}^{2}$ white shrimp vanamei and seaweed distance $45 \mathrm{~cm}$, T4 (10 PL / $\mathrm{m}^{2}$ white shrimp vanamei and seaweed $60 \mathrm{~cm}$ ). Seaweed used Gracillaria sp type $150 \mathrm{~g} /$ bundle with treatment used a long line system placed around the nets plot of $1 \mathrm{~m}^{2}$ in pond culture $300 \mathrm{~m}^{2}$, the reason for the composition of white shrimp Vanamei post larvae 10 (PL 10) and the spacing to get 
White shrimp Vanamei joint in according with the level of Gracillaria sp.

Data includes the growth of absolute weight, survival, Food convertion ratio (FCR) were analyzed varian and test Tukey. The water quality data (temperature, salinity, $\mathrm{pH}, \mathrm{O}_{2}, \mathrm{NO}_{2}$, $\mathrm{NH}_{3}$ ) were analyzed by descriptive.Parameters observed in Gracilaaria sp seaweed growth weight, long growth.

\subsection{Pond and water quality}

Measurement of water quality in ponds by maintaining vanamei shrimp and seaweed shows good water quality and vanamei shrimp and seaweed grow well. The tools used to measure water quality such as hand refractor meters, do meter to measure dissolved oxygen thermometers for measuring temperature, spectrophotometers for measuring nitrite, nitrate, The two nutrients; while nutrient analysis was done using samples of $355 \mathrm{ml}$ which were transported in a styrofoam box. The parameters for water quality were temperature, salinity, $\mathrm{pH}, \mathrm{O}_{2}, \mathrm{NO}_{2}, \mathrm{NH}_{3}$.

\section{Results and Discussion}

\subsection{Absolute growth of white shrimp}

On The results showed that the difference of planting distance of seaweed and white shrimp vanamei showed highly significant ( $P<0,01)$ on growth and survival of white shrimp vanamei and seaweed. The highest absolute weight growth in vanamei white shrimp was T4 ((10 PL / $\mathrm{m}^{2}$ white shrimp vanamei and seaweed $60 \mathrm{~cm}$ ). were treatment T4 (vanamei shrimp $29.25 \pm 0.07 \mathrm{~g}$ ), and seaweed (2919.03 $\pm 8.70^{\mathrm{b}} \mathrm{g}$ ) of white shrimp vanamei survival rate $(98.25 \% \pm 2.25 \%)$, Survival rate of seaweed $\left(93.25 \pm 0.57^{\mathrm{a}} \%\right)$ and FCR (food Conversion ratio) $1.15 \pm 0.09$. Water quality is still feasible optimum by Boyd et al (1982), Kanazawa (1985), Nurjana (2007), Istiyanto and Rachmawati (2016), .

Table 1. Absolute weigh growth based on weight $(\mathrm{g})$, survival on a variety of treatments in polyculture L. vannamei $(\mathrm{g})$ and seaweed

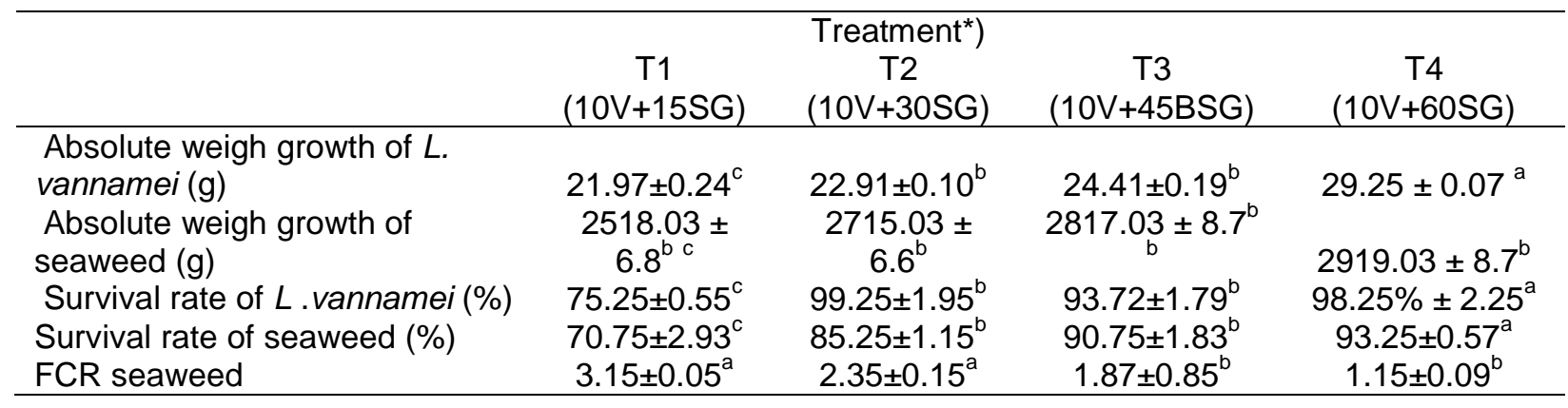

\section{Information}

Treatment were $\mathrm{T} 1=10 \mathrm{~V}+15 \mathrm{SG}\left(10 \mathrm{PL} / \mathrm{m}^{2}\right.$ white shrimp vannamei and seaweed Gracillaria $s p$ distance $15 \mathrm{~cm}), \mathrm{T} 2=10 \mathrm{~V}+30 \mathrm{SG}\left(10 \mathrm{PL} / \mathrm{m}^{2}\right.$ of white shrimp vannamei and seaweed Gracillaria sp distance $30 \mathrm{~cm}), \mathrm{T} 3=10 \mathrm{~V}+45 \mathrm{SG}$ (10 PL / $\mathrm{m}^{2}$ white shrimp vanamei and seaweed Gracillaria sp distance $45 \mathrm{~cm}, \quad \mathrm{~T} 4=$ $(10 \mathrm{~V}+60 \mathrm{SG}) 10 \mathrm{PL} / \mathrm{m}^{2}$ white shrimp vanamei and seaweed Gracillaria sp $60 \mathrm{~cm}$ ). Seaweed used Gracillaria sp type $150 \mathrm{~g} /$ bundle with treatment.
3.1. Water quality of maintenance media on polyculture cultivation technology

Monitoring during the study demonstrated a decent water quality for the cultivation of vannamei milkfish and shrimp with a polyculture system (Table.2), as it uses a biofilter system by filtering water quality in inlet and out let using seaweed (Table 2). 
Table 2. Water quality data resulting from the use of biofilter system

\begin{tabular}{lcc}
\hline Water Quality Parameters & Range & References \\
\hline Oxygen disolved $(\mathrm{mg} / \mathrm{l})$ & $5,25-6,75$ & $>4 \mathrm{mg} / \mathrm{l}^{\mathrm{a}, \mathrm{b}}$ \\
Temperature $\left({ }^{0} \mathrm{C}\right)$ & $26,5-29,5$ & $26,5-35^{\circ} \mathrm{C}^{\mathrm{c}, \mathrm{d}}$ \\
Salinity (ppt) & $20.5-28,5$ & $15-30^{\mathrm{c}, \mathrm{d}}$ \\
$\mathrm{pH}$ & $7.5-8,5$ & $7,5-8,7^{\mathrm{c}, \mathrm{d}}$ \\
Ammonia (mg/l) & $0.01-0,15$ & $<1 \mathrm{mg} / \mathrm{l}^{\mathrm{c}, \mathrm{d} . \mathrm{e}}$ \\
Transparency $(\grave{\mathrm{A}} 1 \mathrm{~cm}-1)$ & 21 & $60-80^{\mathrm{a}, \mathrm{b}}$ \\
$\mathrm{N}-\mathrm{O} 3(\mathrm{mg} \mathrm{L}-1)$ & $0.0-1.45$ & \\
\hline
\end{tabular}

Legend: (Nurjana.2007ª Kanazawa, 1985 ${ }^{\mathrm{b}}$, Kurmaly, $1995^{\mathrm{c}}$, Kanazawa, $1985^{\mathrm{d}}$, Boyd et al.1982 ${ }^{\mathrm{e}}$ ).

Based on Table 3, it is shown that by using biofilter system on water quality management of fish milkfish and shrimp vannamei polyculture system produces decent water quality for polyculture system maintenance and environmentally friendly, because it uses seaweed as biofilter placed in inlet and out $(7,25-5,85 \mathrm{mg} / \mathrm{I})$, the temperature $(25.5 \mathrm{~mm})$ was found to increase the survival rate of $93.73 \pm 0.39 \mathrm{c} \%$ fish and he use of seaweed can increase the growth of shrimp Vanamei because seaweed in addition to acting as a shelter, also plays a role to improve the living media environment of Vanamei shrimp, so it will trigger live shrimp in a good confusion, and able to increase shrimp growth quickly because eat better $96.71 \pm$ $0.85 \mathrm{c} \%$ vannamei shrimp. Water quality during the study showed dissolved oxygen (4.25 - 5.85 $\mathrm{mg} / \mathrm{I})-29.5 \mathrm{oC})$, salinity (19.5 - $27.5 \mathrm{ppt})$, ammonia $(0.02-0.15 \mathrm{mg} / \mathrm{l})$. The content of water quality shows the feasibility for the maintenance of milkfish and shrimp vannamei in accordance with the opinion Nurjana, (2007), Kanazawa (1985), Kurmaly (1985).

\section{Conclusion}

The The results showed that the difference of planting distance of seaweed and white shrimp vanamei showed highly significant $(P<0,01)$ on growth and survival of white shrimp vanamei and seaweed. The highest absolute weight growth in vanamei shrimp was T4 treatment (vanamei shrimp $29.25 \pm 0.07 \mathrm{~g}$ ), and seaweed $\left(2919.03 \pm 8.70^{\mathrm{b}} \mathrm{g}\right)$ of white shrimp vanamei survival rate $(98.25 \% \pm 2.25 \%$ ) and FCR (food Conversion ratio) $1.15 \pm 0.09$. Water quality is still feasible optimum.

\section{Acknowledgements}

We would like to thank the Director of the Director of In accordance with the Letter of Appointment Agreement of Community Service Program Implementation no: 103-24 /UN7P4.3/PM/2018 Dr. Ocky Karna Radjasa who has provided research funding on Hi-Link program, Mayor of Pekalongan, and Chairman of LPPM Undip and Mr. Miftahuddin partner of UKM who have provided pond facilities for this research.

\section{References}

Yuvaraj, D. ,R. Karthik., R. Muthezhilan. 2015. Crop Rotation as A Better Sanitary Practice for The Sustainable Management of Litopenaeus vannamei Culture. Asian Journal of Crop Science. 7(3):219-232.

Kementerian Kelautan dan Perikanan. 2004. Produksi Udang dan Ikan Bandeng di Jawa Tengah, Indonesia [Production of Shrimp and Milkfish in Fisheries Central Java, Indonesia]. Jakarta: KKP. [Bahasa Indonesia].

Marine and Fisheries Agency of Central Java Province. 2004. Basic Data Production Potential and Fisheries Central Java in The Figures. Semarang: Marine and Fisheries Agency.

Miroslav, C., T. Dejana, L. Dragana, Đ. Vesna. 2011. Meat Quality of Fish Farmed in Polyculture in Carp Ponds in Republic of Serbia. J. Tehnologija Mesa. 52(1): 106121.

Jaspe, J. C., C. M. A, Caipang., B. J. G. Elle.2011. Polyculture of White Shrimp, 
Litopenaeus vannamei and Milkfish, Chanos chanos as A Strategy for Efficient Utilization of Natural Food Production in Ponds. J. ABAH Bioflux. 3(2): 96-104.

Istiyanto, S., E. Arini., D. Rachmawati. 2012. Aplikasi IImu dan Teknologi terhadap Kelompok Usaha Polikultur Udang, Ikan dan Rumput Laut (Gracyllaria sp.) berdasarkan Filter Biologis di Desa Mangkang Wetan Kecamatan Tugu, Semarang [Applicaton of Technology and Science in (IbM) Business Group Polyculture of Shrimp, Fish and Seaweed (Gracyllaria sp.) Based on The Biological Filter Mangkang Wetan Village, District Tugu, City Semarang]. Research Report. Semarang: Universitas Diponegoro. [Bahasa Indonesia].

Endrawati, H., S. Istiyanto., A. Indarjo. 2001. Penerapan Teknologi Budidaya Polikultur ikan Nila Gift Pada Kelompok Pembudidaya Tambak [Application and Cultivation Technology Community Business Group Polyculture Nila Gift and Tiger Prawn in Ponds in An Effort to Empower Coastal Communities]. Journal Info. 4(1): 6- 18. [Bahasa Indonesia].

Suyono, S. Istiyanto, D. Rachmawati., T. Yasman. 2010. Penerapan Iptek pad Kelompok Usaha Budidaya Ikan Bandeng (Chanos chanos Forskal) dan Rumput Laut (Gracilaria sp.) di Kelurahan Muara Rejo Kecamatan Tegal Barat Kota Tegal [Application Science and Technology in (IbM) Groups of Fish Farming Milkfish and Seaweed (Gracylaria sp.) in The Village of Muara Church, West Tegal Tegal]. In Suyono, $\mathrm{N}$. Isdarmawan, and N. Zuhri (eds.). Proceeding of National Seminar on Development Strategy for Environmentally-Based Fisheries and Marine. Pancasakti University, Tegal, Indonesia. 9 December 2011. 123-46.

Effendie, M. I. 1979. Metode Biologi Perikanan [Methods of Fisheries Biology]. Bogor: Yayasan Dewi Sri. [Bahasa Indonesia].

Istiyanto, S. 2001. Efek dari Berbagai Variasi Kombinasi Pakan Alami (Tetraselmis chui, Chlorella sp., Brachionus plicatilis Muller, Artemia salina Leach) terhadap Pertumbuhan dan Survival Rate Mangrove Crab (Scylla paramamosain) [Effect of Various Combinations of Natural Feed (Tetraselmis chui, Chlorella $\mathrm{sp}$, Brachionus plicatilis Muller, Nauplius
Artemia salina Leach) on Growth and Survival Rate Mangrove Crab (Scylla paramamosain)]. Paper Presented at the National Seminar of Crustacean 2001. Institut Pertanian Bogor, Bogor. $20-21$ July 2001. [Bahasa Indonesia].

Istiyanto, S. 2001. Pembesaran Kepiting Bakau (Scyla paramamosain) di Tambak dengan Diberi Pakan Rucah pada Dosis Berbeda [Enlargement of Mude Crabs (Scylla paramamosain) in Pond with Feed Trash in Different Dose]. Paper Presented at the National Seminar of Crustacean 2001. Institut Pertanian Bogor, Bogor. 20-21 July 2001. [Bahasa Indonesia].

Istiyanto, S. 2000. Combination Application Chaetoceros sp. and Brachionus plicatilis Muller Against The Growth of Larvae of Milkfish Chanos chanos Forskal. Journal of Marine Science. 19(5): 230-233.

Istiyanto, S. 2008. Engineering of Monoculture Technology for Superintensive System on Mudcrab (Scylla paramamosain) Using Different Feeds on The Growth and Survival Rate. In Hartoko, A. (ed.). Proceedings of International Conference, Geomatic, Fisheries and Marine Science for a Better Future and Prosperity Marine Geomatic Centre (MGC). Semarang, Indonesia. 21-22 October 2008.

Istiyanto, S., D.Rachmawati.2016. Effect of artificial feed on the growth and survival of white shrimp and milkfish in application of innovative polyculture technology. Journal technology (science engineering) 78: 4-2 (2016) 91-98.

Hepher, B., Y. Praginin. 1981. Comercial Fish Farming. New York: John Wiley Sons.

Makwinja, R., F. Kapute. 2015. Bio-economic Evaluation of Tank Raised Tilapia rendalli (Boulenger, 1896) Fed on Varying Dietary Protein Levels. Net Journal of Agricultural Science. 3(3): 62-67.

Murachman., N. Hanani., Soemarno., S. Muhammad. 2010. Polyculture Systrems of Tiger Shrimp (Penaeus monodon Fab), milkfish (Chanos chanos Forskal) and Seaweed (Gracillaria sp.) by Conventional Culture. Journal of Sustainable Development and Nature. 1(1): 2087-3522.

Mangampa, M., Burhanuddin. 2014. Uji Lapang Teknologi Polikultur Udang Windu (Penaeus monodon Fabr.), Ikan Bandeng 
(Chanos chanos Forskal) dan Rumput Laut (Gracilaria verrucosa) di Tambak Desa Borimasunggu, Kabupaten Maros (Field Experiment of Polyculture Technology of Tiger Shrimp (Penaeus monodon Fabr.), Milkfish (Chanos chanos Forskal) and Seaweed (Gracilaria verrucosa) in Brackhiswater Water Pond of Borimasunggu Village, Maros Regency. Jurnal Saintek Perikannan. 10 (1): 30-36. [Bahasa Indonesia].

Hepher, B. 1988. Nutrition of Pond Fishes, Formerly of Fish and Aquaculture Research Station. Cambridge: Cambridge University Press.

Huet, M. 1971. Fish Culture, Breeding and Cultivation of Fish. London: Fishing New (Books) Ltd.

Furnichi, M. 1988. Dietary Requirement in Fish Nutrition in Marriculture. Japan: Japan International Coorporation Agency.

Akiyama, D. M., W. G. Dominy., A. L. Lawrence. 1991. Penaid Shrimp Nutrition for The Commercial Feed Industry. In Akiyama, D. M. and R. K. H. Tan (eds.). Proceedings of the Aquaculture Feed Processing and Nutrition Workshop, Thailand and Indonesia. Singapore. 1925 September 1991 American Soybean Association Singapore. 80-89.

Badan Pengkajian dan Penerapan Teknologi. 2007. Budidaya Udang Windu Secara Tradisional [Tiger Shrimp Cultivation Traditionally]. Research Report. Jakarta: BPPT. [Bahasa Indonesia]

Bautista, M. N. 1986. The Response of Penaeus monodon Juveniles to Varying Protein / Energy Ratios in Test Diets. Aquaculture. 3(3-4): 229-242.

Porchas, M. M, L. R. M. Cordova, M. A. P. Cornejo., J. A. L. Elias. 2010. Shrimp Polyculture: A Potential Provitable Sustainable, but Uncommon Aquacultural Practice. J. Reviews in Aquaculture. 2: 73-85.

Akegbejo., Y. Samsons. 1999. Growth Response and Nutrient Digestibility by Clarias gariepinus Fed Varying Levels of Dietary Periwinkle Flesh as Replacement for Fish Meal in Low-cost Diets. Appl. Trop. Agric. 49(1): 37-41.

Boyd, H. E., Burgess, Pronek., Walls. 1982. Water Quality in Warm Water Fish Pond. Auburn: Auburn University, Aquaculture Experiment Station.
De Silva, S. S., F. Y. Anderson. 1995. Fish Nutrition in Aquaculture. New York: Chapman and Hall.

Halver, J. E. 1980. Fish Nutrition. New York: Academic Press Inc.

Halver, J. E.. T. Lovell. 1989. Nutrition and Feeding of Fish. New York: Van Nostrand Reinhold.

He, H. L., R. Liv. 1992. Evaluation of Dietary Fat Solable Essential of Vitamins A, D, E and $\mathrm{K}$ for Penaeid Shrimp (Penaeus vannamei). Aquaculture. 103: 177-185.

Kanazawa, A. 1985. Nutrition of Penaeid and Shrimp. In: Taki, Y., J. H. Primavera, and J. A. Liobrera (eds). Proceedings of the First International Conference on Culture of Penaeid / Shrimp. Aquaculture Dept. SEAFDEC. Iloilo, Philipphines. 4-7 December 1984. 123-130.

Kurmaly, K. 1995. Shrimp Nutrition and Disease: Role of Vitamins and Astaxanthin. Bangkok: Roche Aquaculture Centre.

Nurjana, M. 2007. Potensi Budidaya Udang di Indonesia [Potency of Shrimp Farming in Indonesia]. In Sudaryono, A. (ed.). Proceedings of the National Seminar of, Aquaculture Society (MAl) Indonesia. Surabaya, Indonesia. 5-7 June 2007.

Steffens. 1989. Principles of Nutrition. England: Ellis Horwood Limited.

Stickney, R. R. 1979. Principle of Warm Water Aquaculture. New York: John Weley and Sons Inc.

Yang, Y., K. Fitzsimmons. 2002. Tilapia Shrimp Polyculture in Thailand. Research Report. Thailand: Asian Institute of Technology.

Davis, J. 2011. Polyculture Opportunities in The Mid-hills of Nepal for Resource Poor Farmers. Ecological Aquaculture Studies \& Reviews. Kingston: University of Rhode Island.

Xie, B., W. Jiang., H. Yang. 2011. Growth Performance and Nutrient Quality of Chinese Shrimp Penaeus chinensis in Organic Polyculture with Razor Clam Sinonovacula constricta or Hard Clam Meretrix meretrix. J. Bulgarian Journal of Agricultural Science. 17(6): 851-858.

Istiyanto. 2009. Pemanfaatan Berbagai Jenis Bakteri Probiotik sebagai Pakan Komersial dari Udang Vannamei [Use of 
Various Types of Probiotic Bacteria (Bacillus, Alcaligenes, Flavobacterium, and Lactobacillus) as The Commercial Feed in Crumble from Vannamei]. Research report] Semarang: Universitas Diponegoro. [Bahasa Indonesia] [In press].

Reksono, B. H., Hamdani., Yuniarti. 2012. Effect of Stocking Density of Gracilaria sp. on The Growth and Survival of Milkfish (Chanos chanos) on The Polyculture Farming System. Journal of Fisheries and Marine. 3(3): 41- 49.

Nikolova, L. 2013. Impact of Some Technological Factors on The Growth of Carp Fish Cyprinidae Reared in Autochthonous Polyculture. J. Bulgarian Journal of Agricultural Science. 19(6): 91-1395.

Yasin, M. 2013. Prospect of Business Organic Shrimp Farming in Polyculture Systems. Scientific Journal Edition March Agriba 1: 86-99.

Dirisu, S. O., B. Muinat., D. M. Yakubu. 2007. Polyculture and Fish Yield in Rice-cumfish Culture System in Dadin Kowa, Gombe, Nigeria. Animal Research International. 4(3): 737-740.

Amal, S. H., S. H. Sayed., E. M. Ibrahim. 2008. Effect of Stoking Rates and Supplementary Feed on The Growth Performance of Blue Tilapia (Oreochromis aureus) and Grass Carp (Ctenopharyngodon idella) Reared in Earthern Pond. In Elghobashy, H., K. Fitzsimmons, and A. S. Diab (eds). Proceedings of 8th International Symposium on Tilapia in Aquaculture. 12-24 October 2008. 949-964.

Aslam, A., G. S. Hossain, M. M. R. Biswas., S. K. Barman., K. Anisulhuq. 2009. Polyculture and Integrated Culture Pattern of Freshwater Prawn in Fresh to Hyposaline Water. Int.J. Sustain. Crop Prod. 4(4): 23-27.

Tacon. 1987. Nutrition and Farmed Fish and Shrimp. [Training Manual]. Brazil: The Essential Nutrients Food anf Agricultural Organization of the United Nations.

Watanabe. 1988. Fish Nutrition and Marineculture. Tokyo: Department of Aquatic Biosciences.
Li, D. S., S. L. Dong. 2000. Summary of Studies on Closed-polyculture of Penaeid Shrimp with Fish and Moluscans. J. Chinese Journal of Oceanology and Limnology. 8: 61-66.

Laxmappa, B., S. M. Khrisna. 2015. Polyculture of The Freshwater Prawn Macrobrachium malcolmsonii (H.M. 98 Istiyanto Samidjan \& Diana Rachmawati / Jurnal Teknologi (Sciences \& Engineering) 78:4-2 (2016) 91-98

Solomon, J. R., M. N. Ezigbo. 2010. Polyculture of Heteroclarias / Tilapia Under Different Feeding Regimes. New York Science Journal. 3(10): 42-57. 